\title{
Power, policing, and language policy mechanisms in schools: A response to Hudson
}

\author{
I A N C U S H IN G if
}

Brunel University London, $U K$

\section{A B S T R A C T}

This discussion is a response to Richard Hudson's response to my article, 'The policy and policing of language in schools' (Cushing 2019). Hudson argues that current education policy in England generally rejects and avoids prescriptivism and sets out to illustrate this in reference to a number of policy documents. As in my original article, I conceive of language policy as $\mathrm{p} /$ Political and one way in which language ideologies get turned into practices, through a series of policy mechanisms such as curricula, tests, and guidance for teachers. I show how these mechanisms do not 'reject' prescriptivism, but explicitly perpetuate it, and thus act as a system of coercion which can lead teachers into reproducing these ideologies in their practice. I argue that Hudson's argument is limited because of its depoliticised stance and understanding of key sociolinguistic concepts and issues, such as 'Standard English', 'linguistic correctness', and language education itself. (Language education policy, language ideologies, critical applied linguistics, schools, England)*

\section{N T R O D U C T I O N}

This discussion is a response to Richard Hudson's response to my article, 'The policy and policing of language in schools' (Cushing 2019). I begin by thanking Hudson for his collegiality during our discussions, and by highlighting the point on which we most clearly agree: that teachers require much more support and training in sociolinguistics in order to understand and address some of the linguistic issues that they encounter in their daily work. I also thank the editors for providing me with the opportunity to respond.

My responses here are largely concerned with Hudson's comments on current language education policy in England (i.e. post 2010 reforms), simply because this was the main focus of the original article. Hudson's response is welcome and valuable, given his long-standing interest in educational linguistics, his power at policy-level and his influence within government — for example, his role

(C) The Author(s) 2020. Published by Cambridge University Press. This is an Open Access article, distributed under the terms of the Creative Commons Attribution licence (http://creativecommons.org/ licenses/by/4.0/), which permits unrestricted re-use, distribution, and reproduction in any medium, provided the original work is properly cited. 0047-4045/20 $\$ 15.00$ 
in writing the grammar glossary that accompanies the current National Curriculum in England (Department for Education 2014:80-98) and his role as an advisor on the primary school grammar, punctuation, and spelling national tests. I have no such overt influence at policy level, yet hope that my previous career as a school teacher and my current role as an academic who conducts classroom-based research helps to further frame this response.

\section{THE REJECTION OF PRESCRIPTIVIS M?}

Hudson claims that policy 'generally avoids prescriptivism', is 'relatively benign on the issue of prescriptivism', and that there have been 'explicit rejections of prescriptivism' in every version of the curriculum. Here are three quite wide-ranging takes on the place/degree of prescriptivism in policy_-'generally avoiding' something is rather different from 'explicitly rejecting' it, so we need to return to the policy documents I originally critiqued to further examine explicit textual traces of prescriptivism and establish a better handle on the language discourses contained within policy. My approach here, as in the original article, is to begin with a set of epistemological principles and methods for analysing language education policy: (i) that policy is $\mathrm{p}$ /Political (i.e. the (p)olitics of everyday activity and the (P)olitics of government); (ii) that policy exists in a series of 'layers', from macro through to micro; (iii) that policy exists as an assemblage of 'mechanisms', including curriculum documents, tests, political discourse, and teacher guidance; (iv) that policy is one way of turning ideologies into practices; and (v) that policy represents one way of maintaining social power and norms. These principles permeate current scholarly work on language policy, especially those that are either engineers and/or products of the 'critical turn', such as Pennycook (2001), Shohamy (2006), and Tollefson (1991). Hudson suggests that my theoretical and methodological starting points serve to delegitimise the claims I make in the article - yet I would contest this by suggesting that his FAILURE to read education policy through a nondiscursive, noncritical, depoliticised lens makes little sense, given the inherently $\mathrm{p} /$ Political nature of language policy documents. In other words, a political document requires a political reading. Even a term such as 'nonstandard' carries political significance, for it is through the presence or absence of 'non' that a variety is socially crafted as being 'different', 'deviant,' and 'nonconformist' (Waugh 1982). Through this reading, 'nonstandard' is simply a label that describes the sociopolitical status of a variety rather than its linguistic 'quality'.

Hudson argues that a political view of Standard English in schools represents a 'minority view', yet this is unsupported by academic references such as to the scholarly literature on critical language education policy. Indeed, Hudson's reading of education policy is highly depoliticised and decontextualised, because it fails to situate the discussions of policy within the sociopolitical and educational climate in which it exists. In my original article, I outlined this climate in detail, but briefly describe the headlines here because it further helps to frame institutional 
ideologies and discourses about language found within current policy. Post 2010 education policy in England is a result of large-scale educational and curriculum reforms which began under the coalition Conservative-Liberal Democrat government, and from 2015 onwards, under the majority Conservative government. The reforms are typically associated with Michael Gove, who spearheaded new policies, assessment systems, and curricula during his time as Education Minister from 2010-2014. These reforms are largely characterised by c/Conservative values and ideologies, Anglocentrism, a return to 'traditional' curricula and pedagogies, high-stakes testing, governmental surveillance, discipline, and strict behaviour management (e.g. Jones 2014; Belas \& Hopkins 2019). As Hudson rightly points out in citing Deborah Cameron's work, language, as is always the case with education policy, gets wrapped up in wider ideologies about schools and what kind of places they 'ought' to be. Language education policy both reflects and influences ideologies about issues in wider society, such as race, culture, and national identity. Given this, it seems imperative that any discussion of language discourses within policy require a consideration of context and the broader educational policies of which they are part. This makes it all the more peculiar that Hudson seems resistant to the idea that language policy is a political act and does not frame his discussion of linguistic conservatism within political conservatism.

Hudson selects a chronology of policy extracts which deal with standard/nonstandard English. Of these, I cannot find textual evidence that policy 'explicitly rejects' prescriptivism, apart from perhaps the extract from the 1990 curriculum which states that pupils 'should be encouraged to respect their own language(s) or dialect(s) and those of others'. This is certainly welcome, although in my view, it does not go far enough to name, disrupt, and reject prescriptivism and its associations with linguistic inequality and stigma. Tracing through the rest of the extracts, I would agree with Hudson in that it appears that policy has shifted towards the conservative end of the descriptive-prescriptive continuum, with, for example, an increasing emphasis on the 'requirement' for students to show competency in Standard English. I would go further than Hudson in a critique here: his extracts of policy show an increasingly uncritical emphasis on Standard English, with a focus on usage rather than attitudes towards linguistic variety and diversity: for example, pupils should 'start to learn' how to use Standard English, and what the 'differences' are between standard and nonstandard varieties. Here, language is about 'competency', 'productivity', and what counts as 'socially acceptable' rather than a focus on descriptive, critical, and analytical pedagogies. Whilst I fully accept that society (and therefore schools) places high 'value' on Standard English and that it ought to be a part of a national curricula, it is also my belief that teaching 'about' it should include its role in perpetuating linguistic inequality, as well as an explicitly differentiating between written and spoken grammar. Both current and previous policy have been inadequate in doing so. Focused analyses on some of the specific curriculum policy documents Hudson cites include Sealey's (1999) critique of primary school policy, who reveals a highly depoliticised 
conceptualisation of Standard English and an implicitly prescriptive stance towards language use' (Sealey 1999:90), whilst Paterson (2010) discusses a lack of clarity in definitions for Standard English in 1999 and 2011 curricula. More in-depth work exploring the politics of prescriptivism and standardisation in schools include, amongst others, Clark (2001) and Crowley (2003). If policy is problematic then, it falls to teachers to combat prescriptivism - and to do so, they require knowledge of critical pedagogies which unpick the tightly woven intricacies between language, context, power, and identity (e.g. Janks 2010), rather than a rather reductive belief that simply 'teaching pupils about standard English' and how standard English 'differs' to nonstandard English is enough to mitigate prescriptive language ideologies.

However, my original article is primarily focused on current, post 2010 education policy and its ability to coerce teachers into reproducing prescriptive ideologies in their practice. Hudson argues that current policy 'consistently contrast[s] Standard English with nonstandard English — not with 'incorrect' or 'bad' English'. In order to evaluate such a claim, a critical stylistic, discourse-historical approach to analysing language policy (e.g. Wodak 2006) is required, in order to pay close attention to the linguistic patterns found within policy to reveal the overt, textual traces of standard language ideologies (e.g. Milroy 2001; Vessey 2019). As in my original article, policy is conceived of as a series of 'mechanisms' (Shohamy 2006), such as curricula, tests, guidance for teachers, and assessment systems. Of these, national curricula are particularly powerful policy mechanisms, with the writers of the current primary curriculum for England claiming to represent 'essential knowledge needed to be an educated citizen' and the 'best that has been thought and said' (Department for Education 2014:6). As consumers and negotiators of these documents, teachers are positioned as the 'managers' of language in schools (Spolsky 2009:90-114), and potential propagators for the kinds of ideologies they contain. 'Standard English' appears sixteen times in the primary school framework, with its first use being as follows:

Pupils should be taught to speak clearly and convey ideas confidently using Standard English. They should learn to justify ideas with reasons; ask questions to check understanding; develop vocabulary and build knowledge; negotiate; evaluate and build on the ideas of others; and select the appropriate register for effective communication. ... This will enable them to clarify their thinking as well as organise their ideas for writing. (Department for Education 2014:10)

This extract appears in the absence of any description of what constitutes 'Standard English' nor why students 'should' use it, yet it is uncritically collocated with academic quality and success: pupils who perform subjectively measured actions such as being able to 'speak clearly', 'think clearly', and 'organise ideas'. In the same document, teachers are instructed that their pupils must 'speak audibly and fluently with an increasing command of Standard English' (Department for Education 2014:16), aligning 'audible' and 'fluent' speech with an exclusive use of Standard English, and so discursively constructing classrooms as sites of 'standard language cultures' (Milroy 2001). Later in the document, teachers are given no 
explanation as to why students 'should use... Standard English forms for verb inflections instead of local spoken forms' in their speech, yet these requirements position teachers into places where prescriptivism is legitimised and normalised. The use of Standard English is framed as a prerequisite for educational achievement, classroom participation, and the conveying of ideas, and as such, is underpinned by the standard language ideology in the way that it biases certain ways of using language and devalues others. The logic of this entails that NOT using Standard English means a lack of clear and fluent speaking and thinking, and so works as a mechanism to suppress and trivialise the use of nonstandard English in schools. This requirement is imposed from the first year of primary school, where students must 'begin to use some of the distinctive features of Standard English in their writing' (Department for Education 2014:25). The standard language ideology is further imposed in the section following the above National Curriculum extract, stating that:

They should be taught the CORRECT use of grammar. They should build on what they have been taught to expand the range of their writing and the variety of the grammar they use. (Department for Education 2014:10, my emphasis)

Hudson acknowledges the 'unfortunate' use of the adjective 'correct' here, yet still maintains that prescriptivism is almost absent from current policy. Discourses about 'correct' grammar serve to gather misinformation about language and present teachers with a model of language which is underpinned by the standard language ideology, essentially underpinned by the myth that there are 'better' and 'worse' ways of using language. Here, teachers are presented with an ADDITIVE model of language, with Standard English being framed as something which 'BUILDS ON what they have been taught' and 'EXPANDS... the variety of the grammar they use' (Department for Education 2014:10, my emphases). The problem with the additive model is that it does not challenge the current sociolinguistic, educational, and sociopolitical order, and instead works to perpetuate it by failing to question the arbitrary power and privilege of Standard English and its speakers. In addition, it is in stark contrast to research which suggests that children acquire sociolinguistic variation (including stance, style, and contextual awareness) simply as part of the typical acquisition process (Smith \& Durham 2019; Moore 2021).

Hudson also defends the grammar glossary that he authored, a nineteen-page document which appears at the end of the curriculum framework. This can certainly be seen as a useful document in that it provides teachers with a set of linguistic definitions, with a detailed discussion of its strengths and weaknesses found in Bell (2015). Whilst this does not include a lengthy discussion of the entry for 'Standard English', Bell argues that it is 'clear enough' and that there is 'no real sense of stigma' (Bell 2015:150). However, myself and other critical linguists would argue that language prescription, stigma, and prejudice cannot be disentangled from ANY use of the phrase 'Standard English', and so from this perspective, the glossary entry is limited in that it offers a highly depoliticised version of Standard 
English. This is reflective of previous curricula (see Sealey 1999:89), yet given the fact that linguists had such an important role to play in the policy making of current curricula, it is perhaps disappointing that the definition fails to recognise the social and political power of Standard English, nor wHY it is seen to be prestigious. Although Hudson points out that sociolinguists have long been involved in the creation of education policy, this does not automatically entail that implicit ideologies and biases did not affect what was produced. Instead, policy consistently reifies Standard English, constructing it as a discrete, 'real', and clearly identifiable category which can be easily taught and assessed, whilst evading any recognition of the standard language ideology and its power. Like Hudson, I acknowledge that government has the 'final say' on policy documents, yet to me this only serves as greater motivation to work with teachers in developing their critical sociolinguistic skills and knowledge, so that they have the tools to question and challenge language policy when needed (see also Snell 2018).

Further policy mechanisms discussed in the original article which Hudson does not address in his response are assessment and gatekeeping measures for teachers and students, such as the Teachers' Standards (Department for Education 2013a). This is a list of eight benchmarks against which teachers' performance in the classroom is judged, either by management or Ofsted. ${ }^{1}$ Trainee teachers who are deemed to 'meet' the standards are granted Qualified Teacher Status, an essential criterion for gaining employment in schools, whereas those who do not fail to qualify and are denied entry to the job market. Standard number three states that teachers must:

demonstrate an understanding of and take responsibility for promoting high standards of literacy, articulacy and the CORRECT use of standard English, whatever the teacher's specialist subject. (Department for Education 2013a:11, my emphasis)

Again, explicit notions of 'correctness' are used to further construct language as a set of 'right/wrong' binaries, with Standard English mobilised in the deployment of rewards and punishments, and as a gatekeeper for membership of the teaching profession. Collocations of vague and subjective terms such as 'high standards' and 'articulacy' with use of the word 'correct' further impose the standard language ideology and deficit notions of linguistic correctness. This standard applies to ALL teachers - not just whatever their 'specialist subject' is, but also whatever their ethnic and regional background is. Given that part of my current role in my university includes the training of teachers in sociolinguistics, I am highly attuned to the power of the Teachers' Standards in how they work as de facto language policy: used to shape curricula, permeating discussions about teacher performance and development, and being used by assessors to judge teachers' practice. As Baratta (2017) shows in relation to schools in England, teachers face considerable pressure to modify their language in ways which 'erases' and further stigmatises their local accents and dialects (see also Britten 2010; Snell 2013). This work suggests that accent prejudice is deeply embedded within school communities, with the Teachers' Standards being used as a buttress for the justification of discrimination. 
Again, it is clear that policy serves to propagate and normalise prescriptivism, despite Hudson's claims otherwise.

Hudson also responds to my criticisms of the primary school grammar tests, stating that questions which require students to 'correct' nonstandard English is the exception, not the general pattern. Whilst Hudson is right that questions which explicitly label nonstandard constructions as 'incorrect' are thankfully sparse, students must still occasionally 'identify' and 'complete' sentences written in nonstandard English, and so the implicit task here is that nonstandard written grammar needs 'changing' and 'fixing'. This is despite work indicating that nonstandard features in speech have a minor impact on writing, and when they do occur, they are actually likely to be a small subset of nonstandard features (see Snell \& Andrews 2017). In forthcoming work (Cushing 2020), I interrogate the test questions in much greater detail, showing that questions which have a 'complete/correct/rewrite' handle are the second most frequently occurring types, following 'identify' questions which assess decontextualised grammatical knowledge (e. g. 'circle the preposition'; 'underline the sentence written in Standard English'). Guidance for test question developers (Standards and Testing Agency 2015) specifies the nonstandard constructions which are deemed to be 'incorrect' and instructs teachers to 'not accept' sentences that are 'grammatically incorrect or written with non-standard English verbs forms or adverbs'. Furthermore, test developer guidance only permits BRITISH English conventions to be permissible responses, framing global variation and 'non-British' varieties of English as 'incorrect' (Standards and Testing Agency 2015:15). As discussed in my original work, these tests were introduced and justified under government recommendations which declared that grammar has a set of 'right and wrong answers' and is a body of knowledge which can be easily assessed (Department for Education 2011). Like other linguists, I welcome the fact that grammar is on the curriculum in England, but cannot endorse the narrow model of grammar as represented in the tests-nor am I alone in rejecting them as inadequate. For example, Crystal (2017) — who Hudson quotes in his response as someone who claims that policy has rejected prescriptivism - has since gone on to criticise the tests and the reductive notions of language contained within them. My own work (Cushing 2018, 2019, 2020) shows teachers criticising the decontextualised, prescriptive version of language assessed in the tests, as well as showing clear evidence of the power of the tests as a de facto policy, coercing teachers into prescriptive practices and pedagogies (see Shohamy 2006:93-109). These concerns are nationwide and shared amongst teachers and academics, for example, as illustrated by the enormous mass of evidence presented to the House of Commons Education Committee in 2017 by 388 teachers, academics, and parents. In their response, the government rejected this evidence-citing an Ofsted report which recommends, amongst other things, an increase in grammar teaching (Ofsted 2012), partly due to the 'lack of emphasis' on Standard English in schools (Ofsted 2012:54). Upon leaving primary school, messages about 'standards' and 'correctness' continue to play a dominant role in the lives of secondary 
students. Although language policy here is more geared towards contextualised grammar (see Cushing 2018), assessment procedures still place a high, uncritical value on Standard English. As one example, 'Standard English' is foregrounded in the mark scheme for GCSE English Language, appearing six times and dictating the requirement for students to, amongst other things, 'write grammatically CORRECT sentences' and 'use grammar CORRECTLY' (Department for Education 2013b:3, my emphases). Again, whilst I understand the need for students to acquire competency in Standard English, current policy does so in a reductive way-with no obvious spaces in the curriculum for students to study language in use, language attitudes, or anything remotely 'social' about language.

T O LER A N C E, D IS C I P L INE, A N D C ONTROL

As I have argued, the frequent collocation of evaluative adjectives ('good', 'correct', etc.) with metalinguistic terms ('Standard English', 'British English', 'grammar', etc.) suggests that post 2010 primary-secondary school education policy mechanisms are underpinned by a set of language ideologies which privilege certain ways of using language, whilst devaluing others. Through a careful examination of these mechanisms, I have shown that they do not 'explicitly reject' prescriptivism as Hudson suggests, but rather work to propagate it through a set of persistent standard language ideologies, across curricula, glossaries, tests, and guidance for teachers. The distinct lack of opportunities for school students to study sociolinguistics (and for teachers to teach it) denies them the chance to understand basic differences between descriptivism and prescriptivism, and so serves to further veil some of the more problematic ideas about language found within policy. Standard English is a social construction, designed and built by the repertoires of speakers who carry social power and prestige: predominantly people who are literate, native, educated, middle-upper class, and white. Linguists have repeatedly shown that it is not the variety of a language which has prestige, but its speakers who have been attributed prestige (e.g. Bourdieu 1977; Milroy 2001:532). The kind of depoliticised view of Standard English found within current policy denies this, often on the grounds that using Standard English simply grants speakers a license to be more socially mobile. Critical takes on policies and pedagogies would instead seek to challenge this, arguing that a political understanding of Standard English is the first step in dismantling and rejecting normative assumptions about language in education (e.g. Corson 1999).

Therefore, I cannot agree with Hudson's argument that it is 'not far from the truth' that prescriptivism in schools is 'dead', nor do I think that we as linguists ought to be using words such as 'tolerate' to describe acceptable attitudes to nonstandard language (Hudson \& Walmsley 2005:615). For me, 'tolerance' is something that we 'put up with', despite a covert dislike to it. A teacher who 'tolerates' nonstandard language in their classroom may not explicitly police or ban it, but this does not equate to an absence of prescriptivism, nor does it mitigate 
the danger of teachers enacting linguistic prejudice and discrimination. Perhaps most importantly, my own analysis of current policy mechanisms, unlike Hudson's, draws on methods from contemporary language policy. As such, it is much more attuned to the sociopolitical and educational contexts in which these mechanisms operate: both through my own lived experience of researching and observing prescriptivism in schools, and through framing current policy in relation to wider shifts in English education towards standards, discipline, surveillance, and control (e.g. Department for Education \& Gove 2011). Schools which have implemented 'tough discipline' and 'zero-tolerance' behavior policies are on the rise in England - for example, Oasis Community Learning, a Multi Academy Trust (MAT) in control of fifty-two schools, has a policy requiring students and staff to 'consistently use Standard English' (Oasis Community Learning 2018:18). These local-level, prescriptive school policies are legitimised and protected by macro-level, government policy.

Hudson cites two additional policy documents (the Kingman Report and the Bullock Report) which he claims show that policy has long abandoned prescriptivism. Whilst there are certainly 'antiprescriptive' messages in these about respect for linguistic diversity and the need to resist notions of 'good/bad' English, a critical reading of these documents reveals similar patterns found in my critiques of 2014 policy. For example, both Millar (1997) and Tollefson (1991) show how discourses about Standard English in both Kingman and Bullock perpetuate the sanitised, depoliticised version of Standard English in failing to include any critical discussion of its sociopolitical power, nor the fact that it is based on the linguistic repertoires of dominant social groups. Another policy source Hudson uses to support his argument is Gross (2010), published by the Centre for Policy Studies, a right-wing think tank who have published multiple prescriptive and socially conservative policies throughout history, including Marenbon's (1987) English, our English, in which the explicit promotion of Standard English in schools is promoted against the 'new orthodoxy' that all dialects are 'equally grammatical'. Gross (2010), which happens to have a foreword by Boris Johnson, is not a research publication, but an anecdote-filled diatribe against 'progressive', 'child-led' education. Hudson's analysis of Gross is misread, for the extract he cites is BEMOANING the 'liberal' approach teachers take to slang and nonstandard grammar in schools, rather than welcoming it. In the document, the extract immediately after Hudson's chosen quotation talks about linguistic 'discrepancies' in 'street language' such as Caribbean, Cockney, Afro-American, and Indian English, and claims that primary school teachers are either intimidated or prohibited by the thought of 'correcting' young people's 'mistakes' (Gross 2010:28). A critical reading of this document is important because of its contextual significance to the current discussion: it was one of many published by the Centre for Policy Studies in 2009-2011 which called for greater discipline and standards in education - including the suggestion of police officers and soldiers running schools - and served as a framing device for the $\mathrm{c} /$ Conservative curriculum reforms introduced by Michael 
Gove. This further shows the importance of reading policy extracts in context, as opposed to citing them as evidence that teachers are welcoming linguistic variation in classrooms, rather than policing it.

\section{TEACHERS AS POLICY AGENTS}

Despite the perceived power of macro-level policy mechanisms, teachers play a key role in the language policy cycle. Hudson and I agree on this, and contemporary language policy research has highlighted the agency and autonomy that many teachers have (e.g. Menken \& García 2010). However, this research-and my own-also shows that teachers can be coerced, intimidated, and socialised into classroom practices they do not necessarily believe in, typically because of the felt pressures of the accountability system and unequal power systems in which they operate. Policy mechanisms such as examination boards, curriculum documents, and language tests play a significant role in these pressures, working as de facto policies which often serve to reproduce monoglossic ideologies and further contribute to the stigmatisation of 'non-normative' ways of using language.

The teachers I interviewed for the original study were all people who reported a lived experience of this pressure. I accept Hudson's point that participants were motivated by their willingness to take part in a study, but this is typical for sociolinguistic interviews, and it is not difficult to find similar data elsewhere in the research literature. For example, Alim (2010:209-11) includes a lengthy extract and discussion from a teacher who has become socialised into dominant views about language, race, and dialect, and essentially serves as a passive conduit for the standard language ideology and the prescriptive pedagogies it produces. In England, myself and other linguists found clear textual traces of prescriptivism in teachers' metalinguistic discourse during workshops we have run for primary school teachers (Snell, Moore, Spencer, \& Cushing 2018), including some of the 'policing' metaphors I discuss in the original article. My own research brings me into contact with hundreds of teachers in schools across England, where I regularly document instances of everyday prescriptivism - overheard conversations, interactions in classrooms, written feedback, and linguistic landscapes on walls and classroom desks. A brief illustration of this is shown in Figure 1, which I collected during a fieldwork visit to a London primary school. This was taped onto every child's desk, serving as an ever-present surveillant linguistic landscape, deployed as a system of control in a similar way to Figures 1 and 2 in my original article.

Figure 1 shows clear intertextual connections between macro- and classroomlevel policy. First of all, this is an example of a strict, 'zero-tolerance' behaviour policy, the type given support by educational ministers and reflective of the extreme shift towards 'tough' discipline controls in schools (e.g. Bennett 2017). Language often gets wrapped up in these policies: whether it be the punitive proscription of 'English-only' classrooms and corridors, or the specific targeting of nonstandard forms, local dialect, slang, accent, and pronunciation. Throughout 


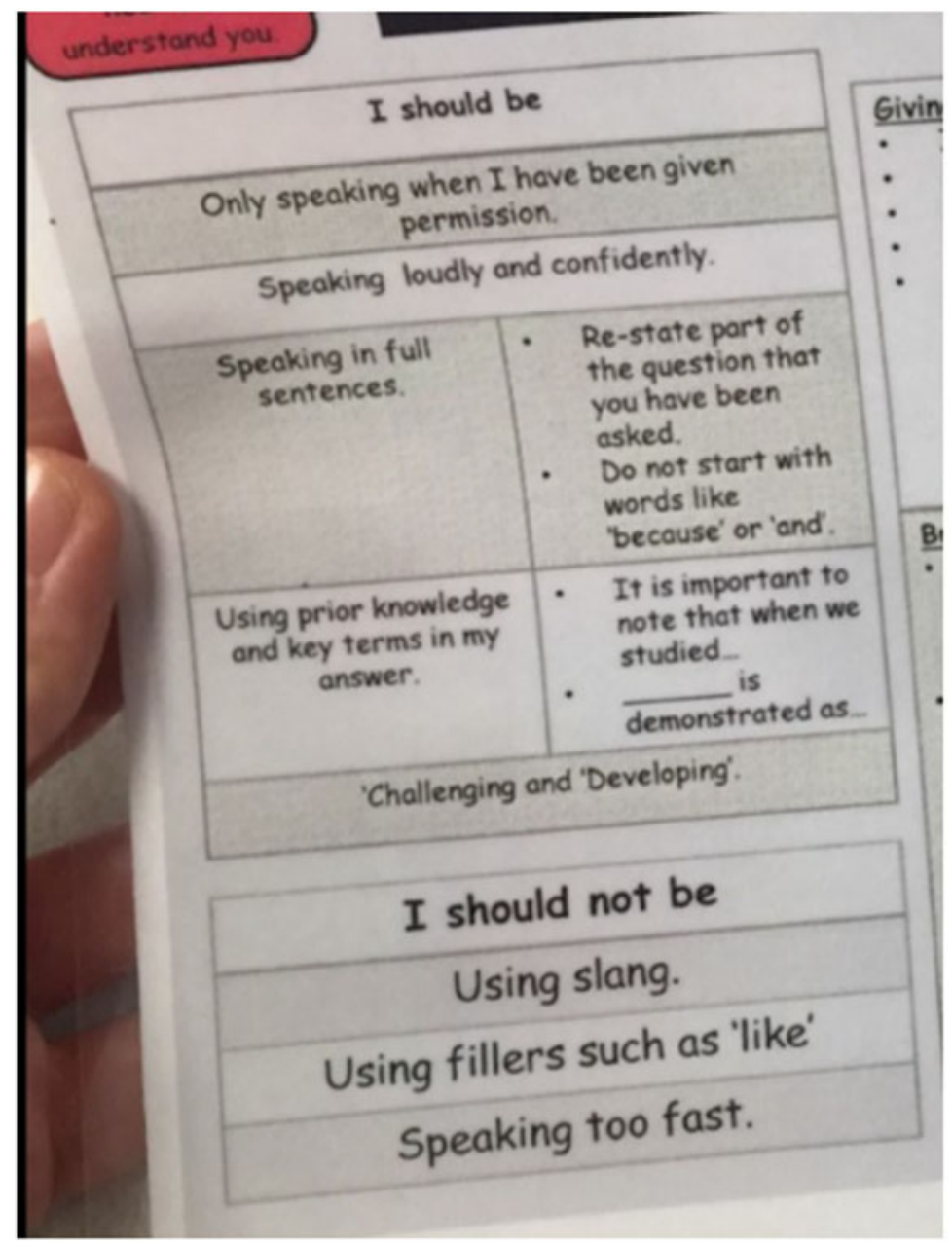

FIGURE 1. Prescriptivism and surveillance in a classroom linguistic landscape.

this discussion, I have shown how discourses about language on current education policy are characterised by vague notions of 'correctness' and 'properness', such as 'high standards of... articulacy', 'speaking clearly', using 'correct grammar', and so on. These discourses are present in Figure 1, framed initially by the modal construction 'I should be...' and prescribing explicit ways of using language: interactional scripts, speaking LOUDLY and CONFIDENTLY, speaking in FULL SENTENCES, NOT using slang, NOT using fillers, NOT starting sentences with 'because', and so on.

It is not fully known how common these types of policies are, nor what the 'social life' of them are in terms of how they affect classroom practice. My 
article would suggest there are clear trajectories between the kinds of language ideologies found across macro-micro level policy, yet, as Hudson rightly notes, we need more data. Ethnography and other longitudinal fieldwork methods would be of value here (see Snell 2013), but this brings about significant challenges in terms of funding, staffing, and access. Work by Godley, Carpenter, \& Werner (2007) is a useful model for tracing prescriptive language ideologies in classroom practice, and a large-scale research project in the UK is urgently needed if we are to better 'join the dots' between layers of language policy and language ideologies.

C O N C L U S I O S , C ONTACT POINTS, A N D

F U T UR E D IR E C T I O N S

Hudson argues that it is not far from the truth that prescriptivism in schools is 'dead', yet my original article and this response - sadly-show that it is very much alive and healthy, fed and nurtured by macro-level policy. However, I would like to end this response by acknowledging the contact points between my own and Hudson's arguments and beliefs about what might be 'done' about some of the issues we discuss. The most obvious and pressing of these would seem to be the fact that teachers need much more training and professional support in sociolinguistics - in terms of both content and pedagogy. Linguists, including myself, Hudson, and others have been making this argument for many years, and I very much hope that this work has countered prescriptivism-but my original article can also be read as a signal that we have not done enough. Perhaps now is the time to address the simple fact that sociolinguistics, critical linguistics, language ideologies, and language attitudes are woefully absent from the majority of school curricula and initial teacher education programmes, as are available resources and support for practicing teachers. As Pennycook (2001:176) argues, language teaching and learning is 'always already political and, moreover, an instrument and a resource for change, for challenging and changing the world'. Whilst I support Pennycook's views, I would also suggest that to be a 'resource for change', teachers need resources themselves - and these include language policy mechanisms which challenge prescriptivism and standard language ideologies, as well as critical, high-quality pedagogical training and guidance. Corson's (1999) book is one excellent example of what support can look like, in which he states that:

If schools uncritically present the standard variety of English as more appropriate and correct than other varieties of English, and better than other languages, then this devalues the other languages and varieties because inevitably students begin to see them as having a lesser role in places like schools where prestige really matters. (Corson 1999:140)

Teachers may well have power and autonomy at the local-policy level (i.e. their classrooms), but without sociolinguistic knowledge they are helpless to understand and resist any top-down policy which may include problematic ideas about language. Radical and CRITICAL sociolinguistics in particular-along with critical 
language pedagogies - are crucial resources here, and we can look to North American teachers and academics as models for good practice-work by Amanda Godley, Jeffrey Reaser, Nelson Flores, Jonathan Rosa, Mariana Souto-Manning, and H. Samy Alim, for example. I hope that my original article and the two responses that have followed it will prompt linguists into greater action and activism. I agree with Hudson that government needs to take a stronger position if it wants to avoid prescriptivism in policy, but to do this, they need to abandon their crude, uncritical, and apolitical stance on what constitutes Standard English. Both Hudson and I share an absolute commitment to tackling linguistic prejudice, discrimination, and stigma in schools, but I have argued that prescriptivism is a part of this. Tackling prescriptivism in language policy mechanisms is a crucial step to tackling language inequality in schools, as is providing teachers with the critical tools in order to better understand the language ideologies contained within them.

\section{N O T E S}

*Thank you to Emma Moore, who kindly provided a set of useful thoughts and suggestions on a draft version of this response, and again to the journal editors.

${ }^{1}$ Office for Standards in Education, an inspection system for all state-maintained schools in England. Schools are judged to be either 'outstanding', 'good', 'requires improvement', or 'inadequate' after around two days of inspection.

\section{R E F E R E N C E S}

Alim, Samy H. (2010). Critical language awareness. In Nancy Hornberger \& Sandra Lee McKay (eds.), Sociolinguistics and language education, 205-31. Clevedon: Multilingual Matters.

Baratta, Alex (2017). Accent and linguistic prejudice within British teacher training. Journal of Language, Identity \& Education 16(6):416-23.

Belas, Oliver, \& Neil Hopkins (2019). Subject English as citizenship education. British Educational Research Journal 45(2):320-39.

Bell, Huw (2015). The dead butler revisited: Grammatical accuracy and clarity in the English Primary Curriculum 2013-2014. Language and Education 29(2):140-52.

Bennett, Tom (2017). Creating a culture: How school leaders can optimize behavior. London: Department for Education.

Bourdieu, Pierre (1977). The economics of linguistic exchanges. Social Science Information 16(6):645-68.

Britten, Nick (2010). Teaching staff rapped over use of local dialect. The Telegraph. Online: https:// www.telegraph.co.uk/education/educationnews/8039833/Teaching-staff-rapped-over-use-of-localdialect.html.

Clark, Urszula (2001). War words: Language, history and the disciplining of English. Oxford: Elsevier.

Corson, David (1999). Language policy in schools: A resource for teachers and administrators. Mahwah, NJ: Lawrence Erlbaum.

Crowley, Tony (2003). Standard English and the politics of language. Basingstoke: Palgrave Macmillan.

Crystal, David (2017). English grammar in the UK: A political history. Supplementary material to Making sense: The glamorous story of English grammar. London: Profile.

Cushing, Ian (2018). Grammar policy and pedagogy from primary to secondary school. Literacy 53(3):170-79. 


\section{IAN CUSHING}

(2019). The policy and policing of language in schools. Language in Society. Online: https:// doi.org/10.1017/S0047404519000848.

(2020). Grammar tests, language ideologies and pedagogical coercion in England's primary schools. London: Brunel University London, ms.

Department for Education (2011). Independent review of key stage 2 testing, assessment and accountability: Final report (The Bew Report). London: Department for Education.

(2013a). Teachers' standards. London: Department for Education.

(2013b). English language: GCSE subject content and assessment objectives. London: Department for Education.

(2014). The national curriculum in England: Key stages 1 and 2 framework document. London: Department for Education.

— \& Michael Gove (2011). New powers for teachers to improve discipline in schools. Online: https://www.gov.uk/government/news/new-powers-for-teachers-to-improve-discipline-in-schools.

Godley, Amanda; Brian Carpenter; \& Cynthia Werner (2007). 'I'll speak in proper slang': Language ideologies in a daily editing activity. Reading Research Quarterly 42(1):100-131.

Gross, Miriam (2010). So why can't they read? London: Centre for Policy Studies.

Hudson, Richard, \& John Walmsley (2005). The English patient: English grammar and teaching in the twentieth century. Journal of Linguistics 41:593-622.

Janks, Hilary (2010). Language, power and pedagogies. In Nancy Hornberge \& Sandra Lee McKay (eds.), Sociolinguistics and language education, 40-61. Bristol: Multilingual Matters.

Jones, Ken (2014). Conservatism and educational crisis: The case of England. Education Inquiry 5(1):89-108.

Marenbon, John (1987). English, our English: The 'new orthodoxy' examined. London: Centre for Policy Studies.

Menken, Kate, \& Ofelia García (eds.) (2010). Negotiating language policies in schools: Educators as policymakers. New York: Routledge.

Millar, Sharon (1997). British educational policy, sociolinguistics and accent. Journal of English Linguistics 25:107-21.

Milroy, James (2001). Language ideologies and the consequences of standardization. Journal of Sociolinguistics 5(4):530-55.

Moore, Emma (2021). Socio-syntax: Exploring the social life of grammar. Cambridge: Cambridge University Press, to appear.

Oasis Community Learning (2018). OCL behaviour for learning policy. London: Oasis Community Learning. Online: https://www.oasisacademyblakenhalejunior.org/uploaded/Blakenhale_Shared/ Behaviour_for_Learning_Policy.pdf.

Ofsted (2012). Moving English forward: Action to raise standards in English. London: Ofsted. Online: https://assets.publishing.service.gov.uk/government/uploads/system/uploads/attachment_data/ file/181204/110118.pdf.

Paterson, Laura (2010). Grammar and the English National Curriculum. Language and Education 24(6):473-84.

Pennycook, Alastair (2001). Critical applied linguistics. London: Routledge.

Sealey, Alison (1999). Teaching primary school children about the English language: A critique of current policy documents. Language Awareness 8(2):84-97.

Shohamy, Elana (2006). Language policy: Hidden agendas and new approaches. London: Routledge.

Smith, Jennifer, \& Mercedes Durham (2019). Sociolinguistic variation in children's language. Cambridge: Cambridge University Press.

Snell, Julia (2013) Dialect, interaction and class positioning at school: From deficit to difference repertoire. Language and Education 27(2):110-28.

(2018). Critical reflections on the role of the sociolinguist in UK language debates. Language in Society 47(3):368-74. 
POWER, POLICING, AND LANGUAGE POLICY MECHANISMS

\& Richard Andrews (2017). To what extent does a regional dialect and accent impact on the development of reading and writing skills? Cambridge Journal of Education 47(3): 97-313.

; Emma Moore; Sarah Spencer; \& Ian Cushing (2018). Developing primary school teachers' knowledge about grammar and language. Workshop delivered at the University of Leeds.

Spolsky, Bernard. (2009). Language management. Cambridge: Cambridge University Press.

Standards and Testing Agency (2015). English grammar, punctuation and spelling test framework. London: Standards and Testing Agency. Online: https://dera.ioe.ac.uk/16196/1/2013-2015_ keystage2_english_grammarpunctationandspelling_test_framework.pdf.

Tollefson, James (1991). Planning language, planning inequality: Language policy in the community. London: Pearson.

Vessey, Rachelle (2019). Corpus approaches to language ideology. Applied Linguistics 38(3):277-96.

Waugh, Linda. (1982). Marked and unmarked: A choice between unequals in semiotic structure. Semiotica 38:99-318.

Wodak, Ruth (2006). Linguistic analyses in language policies. In Thomas Ricento (ed.), An introduction to language policy: Theory and method, 129-34. Oxford: Blackwell.

(Received 1 April 2020; revision received 13 April 2020; accepted 13 April 2020)

Address for correspondence: Ian Cushing Department of Education Brunel University London Uxbridge, UB8 3PH, UK ian.cushing@brunel.ac.uk 